\title{
THE RELATIONSHIPS AMONG INTERPRETIVE SERVICE QUALITY, SATISFACTION, PLACE ATTACHMENT AND ENVIRONMENTALLY RESPONSIBLE BEHAVIOR AT THE CULTURAL HERITAGE SITES IN XI'AN, CHINA
}

\author{
ChENG, T. E. ${ }^{1,2}-$ WANG, J. ${ }^{3}-$ CAO, M. M. ${ }^{2 *}-$ ZHANG, D. J. ${ }^{3}$ - BAI, H. X. ${ }^{1}$ \\ ${ }^{1}$ School of Foreign Languages, Northwest University, Xi'an, China \\ (e-mail:958632991@qq.com-T.E.Cheng,374220178@qq.com-H.X. Bai) \\ ${ }^{2}$ College of Urban and Environmental Sciences, Northwest University, Xi'an, China \\ ${ }^{3}$ College of Geography Sciences, Shanxi Normal University, Linfen, China \\ (e-mail:1565612766@qq.com-J.Wang,112936666@qq.com-D.J. Zhang) \\ *Corresponding author \\ e-mail: chengshi@nwu.edu.cn \\ (Received $31^{\text {st }}$ May 2018; accepted $2^{\text {nd }}$ Aug 2018)
}

\begin{abstract}
The present study investigated the causal relationships among interpretive service quality, satisfaction, place attachment and environmentally responsible behavior. 1800 tourists visiting five historic heritage sites in Xi'an, China were surveyed and 1408 valid questionnaires were collected. The validity and reliability of the data were analyzed by using SPSS 22.0 and the structural equation model (SEM) was tested using AMOS 24. The findings of the study showed that interpretive service quality has direct and positive effect on satisfaction and satisfaction directly impacts place attachment and environmentally responsible behavior respectively. In addition, interpretive service quality exerts indirect influence on place attachment and environmentally responsible behavior respectively through satisfaction, indicating the mediating role of satisfaction in the relationship between interpretive service quality and place attachment as well as that in the relationship between interpretive service quality and environmentally responsible behavior. Moreover, the study demonstrated that place attachment influences environmentally responsible behavior directly. In the end, management implications about the improvements in interpretive services at cultural heritage sites are suggested in order to sustain sustainable development of heritage tourism.
\end{abstract}

Keywords: interpretation outcome, behavioral intention, heritage tourism, structural equation modeling

\section{Introduction}

Xi'an $\left(34^{\circ} \mathrm{N}, 108^{\circ} \mathrm{E}\right)$, the capital city of Shaanxi province, China, has a history of around 3100 years and 13 dynasties in Chinese history established their capitals in this city. As a result, it boasts a wealth of historical relics left by past dynasties and enjoys a reputable Natural History Museum in China (Ma, 2007, p. 139). An overwhelming majority of these historical relics have been preserved and developed into tourist attractions. Reflecting the economic, social and cultural development in history, these sites carry the heritage creators' values, aesthetical standards and spiritual needs (Hall and McArthur, 1998). The meaning ascribed to the sites mean more to tourists than what the physical artifacts do to them (Graham, 2007). Unfortunately, many tourists cannot understand the profound meaning carried by such sites (Risk, 1982, p. 195). Heritage tourism management agencies provide interpretive services to help visitors understand values inherent in the heritages to enrich their experiences (Knudson et al., 2003). It is claimed that the enhanced experiences enable tourists to increase 
knowledge, which results in their behavioral change (Moscardo, 2014). Previous studies examined the influence of interpretation on environmentally responsible behavior (ERB) and found the former could help elicit the latter (Powell and Ham, 2008). Some researchers believed that interpretation also affected tourists' emotional attachments to visited place. Carr (2004) as well as Knudson, Cable and Beck (2003) viewed that emotional attachments to natural and cultural resources were meaningful for tourists to understand the essence of a place. Unfortunately, very limited empirical studies explored the relationship between interpretation and emotional attachment.

Past ERB literature indicated place attachment (Ramkissoon et al., 2013; Lee, 2011) and satisfaction (Lee and Moscarbo, 2005) predicted ERB. However, the relationships among satisfaction, place attachment and ERB have not been tested in the field of interpretation. Since interpretation is demonstrated to influence tourists' behaviors, there might be causal relationships among the above 4 variables. Besides, although some researchers held that quality interpretation could enable tourists to exhibit ERB (Powell and Ham, 2008), few quantitative studies have been conducted to examine the outcomes of it. Most of the existing studies were conducted in community-based (Lee et al., 2013b) and natured-based tourism destinations (Kim, 2011; Lee, 2009). Very limited such studies have been conducted at cultural heritage sites. Skibins et al. (2011) argued that it was very necessary to fully study interpretation outcomes if long-term management of tourism resource relied on sustainable use by visitors.

Therefore, the purposes of this study are:

1. To explore the relationship between interpretive service and place attachment.

2. To investigate the causal relationship between interpretive service and ERB.

3. To examine whether interpretive service influences satisfaction.

4. To study whether satisfaction affects place attachment.

5. To explore the relationship between satisfaction and ERB.

6. To test whether place attachment impacts ERB at cultural heritage site.

Selecting 5 heritage sites in Xi'an area as study sites, this empirical study will not only contribute to conceptual models related to interpretation outcomes but will benefit the sustainable development of heritage tourism in Xi'an in the long run.

\section{Literature review}

\section{Interpretation service}

Interpretive services at heritage sites include personal interpretation given by tour guides and on-site interpreters as well as non-personal interpretive services delivered through various media such as signage, on-site panels, brochures, exhibits, visitor centre etc. (Skibins, 2010). Tourists often depend on interpretation to understand the inherent meaning and value of heritage sites, which helps them experience a worthwhile and enjoyable trip. From the perspective of tourism management, they provide interpretive services to help tourists understand the embodied meaning in heritages resources (Knudson et al., 2003), express their requirements for tourists and inspire them to protect heritage. Obviously, interpretation serves as a communication bridge between tourists and tourism management.

Tilden (2007) defined interpretation as "an educational activity which aims to reveal meanings and relationships through the use of original objects, by firsthand experience, and by illustrative media, rather than simply to communicate factual information". His 
ideas about interpretation had enormous influence on the researchers of later generations. Although researchers after Tilden modified the definition of interpretation (Moscardo, 2014; Poria et al., 2009), the core part of educational function emphasized by Tilden remains. This can be seen from the research focus of some researchers. Munro et al. (2008) and Skibins et al. (2011) found most of studies concerning focused on evaluating knowledge increase of tourists after they experienced interpretive services and these studies also reported knowledge increase (Mace, 2013; Morgan and Hwang, 2014; Powell and Ham, 2008). However, besides educational functions, interpretation has more functions like enhancing tourists' experiences, fostering positive attitudes and behaviors among tourists (Ham and Weiler, 2006), providing them with opportunities to form emotional link to the visited site (Larsen, 2003) etc. Some studies showed that contemporary tourists hoped to gain some emotional experience through interpretation rather than just getting an educational experience (Poria et al., 2009). It is argued that the emotional link between the tourist and the place should be explored to understand and manage historic settings (Poria, 2006). Unfortunately, the affective outcome of interpretation is usually ignored. In addition, effective interpretation was believed to prompt more environmentally responsible behavior among tourists (Ballantyne et al., 2011), which is one of the core goals of interpretation (Ward and Wilkinson, 2006). For instance, the study conducted by Tubb (2003) found that interpretation provided in Dartmoor National Park in the UK encouraged tourists to behave more respectfully towards the local environment. The findings of Powell and Ham (2008) also showed that quality interpretation during the ecotourism experience could help tourists show general environmental behavioral intentions. In short, previous literature showed that interpretation impacted ERB, but such studies mainly used national parks or other nature-based settings.

\section{Tourist satisfaction}

In the field of tourism industry, many studies examined the antecedents of tourist satisfaction and its outcomes. According to past literature, the antecedents contributing to overall tourist satisfaction involve leisure service of destination attributes (Bernini et al., 2014), positive destination attributes (Battour et al., 2014; Zabkar et al., 2010), service quality (Song et al., 2010), place attachment (Yuksel et al., 2010). The consequences of satisfaction involved in the past studies mainly include its positive influence on destination loyalty (Yuksel et al., 2010), place attachment (Ramkissoon et al., 2015; Su et al., 2011), behavioral intention (Chen, 2010) and ERB (Davis et al., 2011).

Studies examining the link between interpretive services and satisfaction found the former had direct and positive effect on the latter (Huang et al., 2015; Ham and Weiler, 2007; Lee, 2009). However, these studies mainly focused on personal interpretation and very limited studies examined the impact of both personal and non-personal interpretive services on satisfaction. Although interpretation provided by tour guide is proved to be more effective than non-personal ones (Hughes, 2004), it is still important to study the outcome of non-personal ones since most of the tourists at cultural heritage sites in China depend on them to understand the inherent meaning of visited sites. Besides, past research mainly studied the relationship between interpretive service and satisfaction in nature-based context and that in historic heritage context is usually ignored. What is more, the above studies failed to assess the quality of interpretation, which may affect the accuracy of their research findings. 
The findings of previous literature showed inconsistent or opposite results about the relationship between satisfaction and place attachment. Some studies demonstrated that satisfaction affected place attachment (George and George, 2004), while other studies indicated opposite results. (Prayag and Ryan, 2012; Yuksel and Bilim, 2010). Research of the relationship between the two mainly examined satisfaction with service quality (Su et al., 2011), satisfaction with attractiveness of a destination (Hou et al., 2005) and overall level of satisfaction (Petrick et al., 1999). Very limited studies were conducted to study the relationship between interpretive service satisfaction and place attachment and no relative studies have ever been conducted at cultural heritage settings.

Satisfaction was shown to influence customers' behavioral responses in the field of marketing (Baker and Crompton, 2000) and in the field of recreation and tourism satisfaction was viewed as a factor influencing ERB (Lopez-Mosquera and Sanchez, 2011; Powell and Ham, 2008) at national parks or other nature-based settings. For instance, Ramkissoon et al. (2013) surveyed tourists visiting the Dandenong Ranges National Park, Australia to explore the relationships among place attachment, place satisfaction and pro-environmental behavioral intentions and found that visitors' satisfaction with the visited site influenced their on-site behaviors. The existing literature concerning the relationship between the two variables mainly focused on satisfaction with travel experience or with the visited sites at natured-based settings. No study has ever been conducted to examine the relationship between satisfaction with interpretive service quality and ERB at historic heritage sites.

\section{Place attachment}

Place attachment is an affective and emotional bond that people develop with a place (Low and Altman, 1992) and the term "place attachment" highlights a positive bond between the two (Trentelman, 2009). Researchers in different fields view it as a multi-dimensional construct including place dependence, place identity, place social bonding (Ramkissoon et al., 2013) and place affect (Hinds and Sparks, 2008). Among these dimensions, the most widely accepted and frequently studied ones are the former two. Place dependence emphasizes functional attachment to a place because the place can provide necessary resources or facilities to meet the individual's specific activity needs (Williams and Roggenbuck, 1989). Place identity reflects the symbolic importance of a place to a person (Williams and Vaske, 2003). In the field of tourism, researchers have studied factors predicting place attachment as well as effects of it. According to past literature, some factors like service quality (Alexandris et al., 2006), attractiveness of a destination (Xu and Zhang, 2016), environmental sensitivity (Cheng and $\mathrm{Wu}, 2013$ ), activity involvement (Xu and Zhang, 2016), satisfaction with service quality (Su et al., 2011) etc. predict place attachment.

Lee et al. (1997) emphasized that psychological attachment was important in understanding tourist behavior in explaining behavioral phenomena. Several researchers have found that place attachment was a positive predictor of ERB (Halpenny, 2010; Lee, 2011). According to the findings of previous studies, when tourists were highly attached to tourist destinations, they were more likely to exhibit their ERB (Cheng et al., 2013; Ramkissoon et al., 2013). For example, Cheng et al. (2013) examined the causal relationships among place attachment, destination attractiveness and ERB and the study results showed that place attachment was positively associated with stronger ERB. 
Past studies mainly focused on place attachment elicited by destination attractiveness (Cheng et al., 2013), environmental sensitivity (Cheng et al., 2013) and satisfaction with service quality of the resort ( $\mathrm{Su}$ et al., 2011). To date, no research has ever explored whether satisfaction with interpretive service will affect place attachment. In addition, studies of place attachment are extremely limited in interpretation literature (Goldman et al., 2001). For further understanding the nature of human place bonding, it is necessary to study the relationship between place attachment and ERB in the field of interpretation. Research into place attachment is classified into three contexts: personal context, natural environment context and community context (Raymond et al., 2010), but very limited research has been conducted to investigate the relationship between place attachment and ERB in the context of historic heritage site. Evidence shows that sustainability practices in national parks and other natural areas can be improved by fostering place attachment (Halpenny, 2010) and by encouraging ERB among visitors (Ballantyne et al., 2009) and such an inference may also apply to sustainable development of cultural heritage tourism.

\section{Environmentally responsible behavior}

Environmentally responsible behavior (ERB) is defined as an intentional action of an individual or group to directly or indirectly benefit the environment (Stern, 2000) and such action contributes to tourism resource protection and conservation (Lee, 2011). Many studies of ERB borrowed the definition given by Sivek and Hungerford (1990) which limits ERB to nature-based settings. In studying ERB at various settings, the attitude-behavior model is frequently employed. According to the theory of reasoned action (Fishbein and Ajzen, 1975) and the theory of planned behavior (Ajzen, 1991), attitude significantly affects an individual's behavior and it is an important predictive variable of behavior (Lee et al., 2013a). According to the theory of reasoned action, the best predictor of behavior is the intention to adopt the behavior (Halpenny, 2005). In empirical studies, it is rather difficult to measure the actual ERB of tourists. Based on the above theory, most studies measured behavioral intentions of visitors instead of their actual behaviors. Smith-Sebasto and D'Costa (1995) classified ERB into six categories including civic action, educational action, financial action, legal action, physical action as well as persuasive action. Compared with measurement scales developed by other scholars for ERB, the construct of ERB developed by Smith-Sebasto (1995) seemed to be more holistic (Lee et al., 2013b) and his categories of environmental action are widely used by tourism scholars to evaluate personal ERB (Ballantyne et al., 2011). ERBs are usually measured from two dimensions: general ERBs and specific ERBs (Lee et al., 2013b).

ERB has been widely studied in the field of tourism. Past research found that factors predicting ERB included place attachment (Lee, 2011; Ramkissoon et al., 2013), environmental attitudes (Schultz et al., 2004), commitment to the natural environment and tourist motivations (Lee, 2011), perceived value, satisfaction and activity involvement (Davis et al., 2011; Ramkissoon et al., 2014), environmental knowledge and environmental sensitivity etc. (Cheng and $\mathrm{Wu}, 2013$ ). The studies of ERB that involved satisfaction mainly focused on visitors' satisfaction with the global setting at tourism destinations or their travel experience. To date, no study has ever examined whether satisfaction with interpretive service may lead to visitor's adoption of ERB. Some scholars argued that interpretive services helped facilitate tourists' ERB (Ballantyne et al., 2011). Marion and Reid (2007) reviewed the theoretical and empirical 
studies concerning interpretation outcomes in the US and found that most of the interpretation services could effectively modify visitors' behaviors. However, most of the past research of ERB indicated that interpretive services had impacts on ERB mainly as a result of visitors' knowledge increase. Since satisfaction is considered one of the antecedents of ERB, the present study views that satisfaction with interpretive services may impact visitors' ERB. In addition, past studies only studied ERB at naturebased settings and very limited research has ever assessed ERB at historic heritage settings. In addition, the relationship between place attachment and ERB is frequently studied in the field of recreation and tourism, but no study has ever been conducted to evaluate such a relationship in interpretation literature. This research attempts to study whether satisfaction with interpretive service affects tourists' ERB and the relationship between place attachment and ERB in the field of interpretation in historic heritage context in order to enrich the literature of ERB.

Based on the above literature review, the following hypotheses and theoretical model (Fig. 1) are proposed:

$\mathrm{H}_{1}$ : Interpretive service quality directly and positively influences place attachment;

$\mathrm{H}_{2}$ : Interpretive service quality directly and positively influences ERB.

$\mathrm{H}_{3}$ : Interpretive services directly and significantly influence tourist satisfaction;

$\mathrm{H}_{4}$ : Satisfaction directly and positively affects place attachment;

$\mathrm{H}_{5}$ : Satisfaction directly influences ERB.

$\mathrm{H}_{6}$ : Place attachment directly and significantly influences ERB

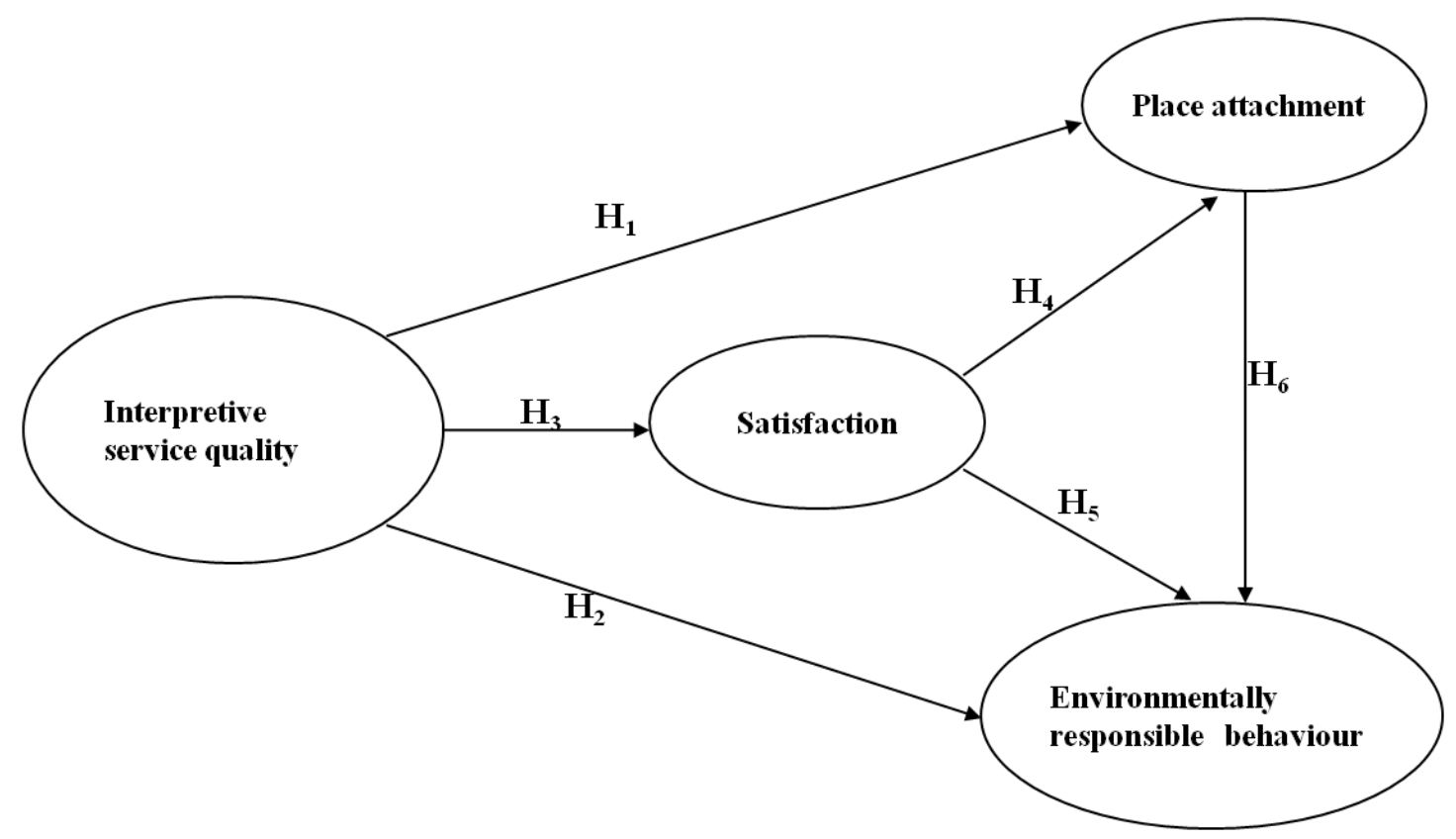

Figure 1. The theoretical model of heritage site tourists

\section{Research methods}

\section{Study sites}

The study sites include the following five historic heritage sites in $\mathrm{Xi}$ 'an, China (Fig. 2). (1) Emperor Qinshihuang's Mausoleum Site Museum is the only cultural historic heritage in Shaanxi province inscribed on the World Heritage List. It is China's 
largest ancient military museum representing an epitome of the powerful army in the Qin dynasty (221B.C.-207B.C.). (2) Huaqing Palace which characterizes culture of the Tang dynasty (618A.D.-907A.D.) is famous for hot springs, imperial palaces, imperial gardens and historical events in the Tang dynasty. (3) Dayan Pagoda and Tang Paradise are two neighboring historic sites located in Xi'an city. Dayan Pagoda enjoys a history of over 1300 years and is famous for storing Buddhist scriptures. Tang Paradise is a historic site featuring culture of the Tang dynasty. (4) Mausoleum of Yellow Emperor is a holy land to worship the Chinese ancestor-Xuanyuan Emperor and it is claimed No. 1 Mausoleum in China. (5) Honored as royal temple, Famen Temple has a history of 1700 years and is a holy land of Buddhism for storing Sakyamuni’s finger bone.

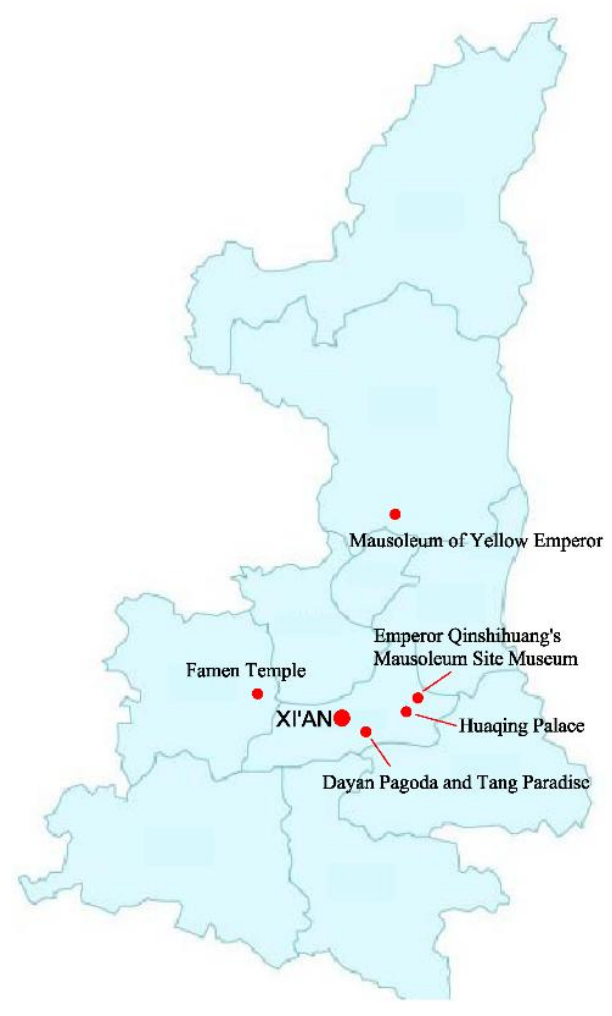

Figure 2. The map of study location

\section{Data collection}

The questionnaire consists of 3 sections. The first section introduces interpretive services and programs at the heritage sites and one question is designed to investigate the interpretive services used by tourists. The second section consists of 47 items devised to examine tourists' evaluation of interpretive service quality, satisfaction, place attachment and ERB. The third section is the profile of respondents. The pretest of 180 questionnaire surveys was conducted and data analysis was valid and all the items were kept. Based on the suggestions given by some respondents and staff of management agencies, the wording was revised in order to help tourists better understand each item. The final formal questionnaire was established based on the pretest results.

The graduates who were trained how to hand out questionnaires went to the heritage sites to conduct the survey. Convenience sampling was used to survey respondent 
tourists at the exits of the historic sites between May and September 2015. It took about $10 \mathrm{~min}$ for each respondent to answer all the questions on the questionnaire. A total of 1800 questionnaires were distributed and 1408 valid ones were collected (Table 1).

Table 1. Survey sample at each heritage site

\begin{tabular}{c|c|c|c}
\hline Heritage sites & Total surveys & Valid sample & Sampling dates \\
\hline $\begin{array}{c}\text { 1. Emperor Qinshihuang's } \\
\text { Mausoleum Site Museum }\end{array}$ & 200 & 154 & May 1-3, 2015 \\
\hline 2. Huaqing Palace & 193 & 143 & June 23-24, 2015 \\
\hline $\begin{array}{c}\text { 3. Dayan Pagoda and Tang } \\
\text { Paradise }\end{array}$ & 1007 & 841 & July 2015 (8 days) \\
\hline $\begin{array}{c}\text { 4. Mausoleum of Yellow } \\
\text { Emperor }\end{array}$ & 200 & 139 & August 11-12, 2015 \\
\hline 5. Famen Temple & 200 & 131 & September 19-20, 2015 \\
\hline Total & 1800 & 140 & \\
\hline
\end{tabular}

\section{Measurement of constructs}

This study adopted SERVPERF model to assess interpretative service quality including five dimensions like tangibles, empathy, assurance, responsiveness and reliability. 22 items were borrowed and adapted from Cronin and Taylor's (1994) research findings. Satisfaction was evaluated from a holistic perspective and 4 items borrowed and adapted from the research results of Oliver (1980) and Ramkisoon et al. (2013) were used to measure tourists' global satisfaction with interpretive services. The construct of place attachment consisted of two dimensions: place dependence and place identity. 13 items borrowed and adapted from Williams and Roggenbuck's (1989) as well as Morgan's (2009) research findings were used to measure place attachment. Two dimensions were included in ERB. 8 items adapted from Smith-Sebasto and D' Costa's work (1995) were used to measure ERB. All the above-mentioned items were scored on a 7 -point Likert scale $(7=$ strongly agree; $1=$ strongly disagree). Demographic variables of the questionnaire included gender, age, marital status, education, city of residence, companion, number of visiting times, visit duration and purposes of visiting the sites.

\section{Results of the study}

\section{Respondent profiles}

There were more female respondents (54.4\%) than male ones $(45.6 \%)$. 85.6\% were between 18 and 50 years old. 50.6\% were married and $62.2 \%$ received college education. More than half of the respondents $(58.7 \%)$ came from outside of Shaanxi and $38.9 \%$ were locals. Only 1.6\% came from Hong Kong, Macao and Taiwan. $76.6 \%$ were accompanied by friends or family members and $12.6 \%$ were with group tour. Most of the respondents $(68.5 \%)$ visited the destinations for the first time. It took most of them (76.7\%) 2-3 h to visit the sites. The motivation of $58.9 \%$ was to seek nostalgic experience and $55.1 \%$ went to relax themselves. $41.4 \%$ went to broaden their horizon and $36.4 \%$ visited the places due to the site reputation. Various interpretive services 


$$
\text { - } 6325 \text { - }
$$

were used by the tourists: personal interpretation (51.3\%), signage (41.4\%), digital interpretation $(11.6 \%)$, printed materials $(12.8 \%)$, visitor center $(10.4 \%)$, films $(6.6 \%)$, projects participation (7.3\%) and websites (7.2\%) (Fig. 3).

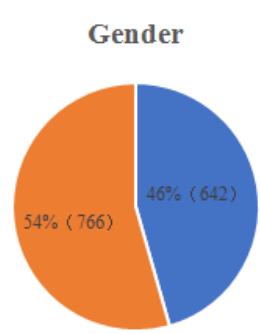

- Male - Female

Marital status

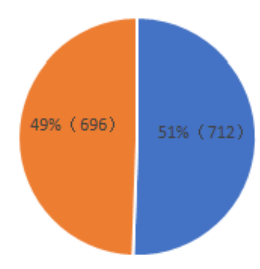

-Unmarried " Married
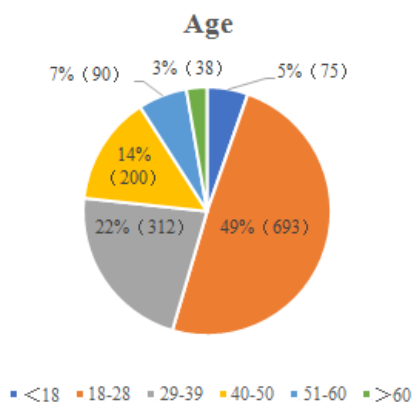

Companions

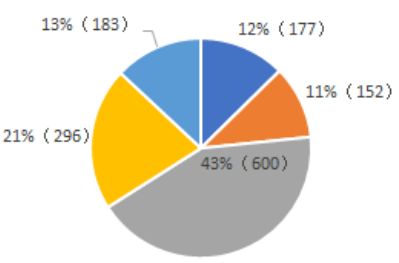
- Package tour
"With friends
- With friends and family
- Travel alone

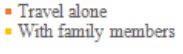

Education

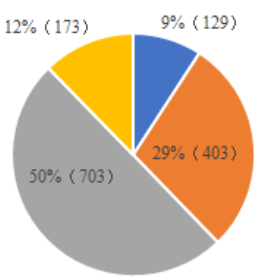

- Junior high school \& below - Senior high school

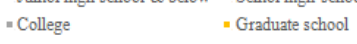

Residence

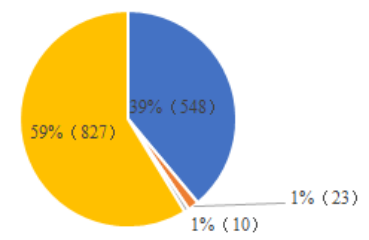

- Shaanxi province

- Hong Kong, Macao and Taiwa

"Overseas
"Mamland provinces outside Shaanxi

Past experiences

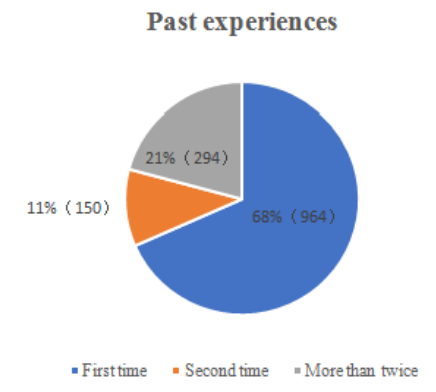

- Firstime = Second time "More than twice
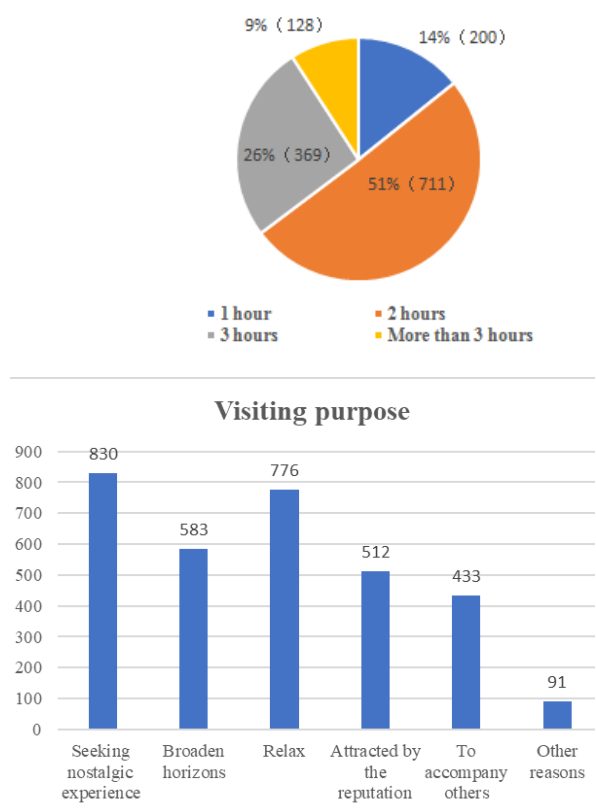

Interpretive services used

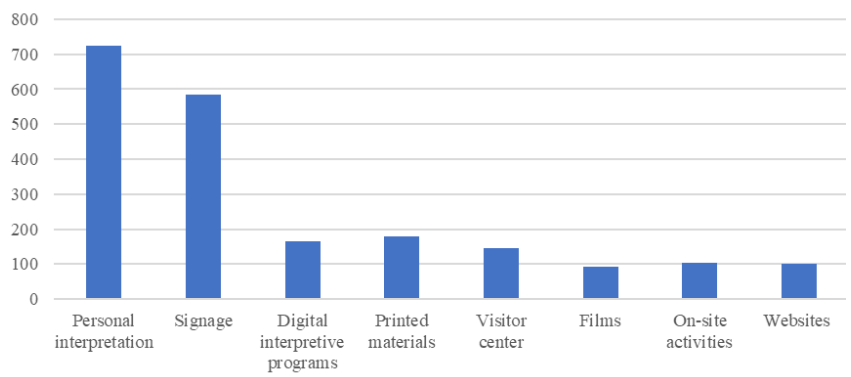

Figure 3. Demographics of the respondents

\section{Data analysis}

SPSS 22.0 was used to analyze the collected data. The reliability and validity were tested to find whether the instrument had good internal consistency. Principal component analysis and varimax rotation were used for factor analysis and convergent factors extraction and all the items were kept. In the end, the extracted common factors 
as well as the corresponding factor loadings were obtained (Table 2). The Cronbach's alpha (between 0.72 and 0.99 ) exceeded the threshold value of 0.7 , indicating a good level of internal of consistency of all the constructs in the study. In addition, factor loadings (between 0.57 and 0.87 ) of all the variables were significant $(\mathrm{p}<0.001)$. Composite reliability $(\mathrm{CR})$ exceeded 0.60 , indicating all the constructs in the research had good reliability (Table 2).

Table 2. The results of reliability and validity analysis

\begin{tabular}{|c|c|c|c|c|}
\hline Measured variables and dimensions & $\begin{array}{l}\text { Cronbach } \\
\text { Alpha }\end{array}$ & $\begin{array}{l}\text { Factor } \\
\text { loadings }\end{array}$ & $\mathbf{C R}$ & AVE \\
\hline \multicolumn{5}{|l|}{ Interpretive service quality } \\
\hline Tangibles & 0.77 & & 0.82 & 0.53 \\
\hline $\begin{array}{l}\text { The digital interpretive programs at the heritage } \\
\text { site provide effective interpretation }\end{array}$ & 0.74 & 0.78 & & \\
\hline $\begin{array}{l}\text { The signage and tour route signs are easily } \\
\text { spotted }\end{array}$ & 0.79 & 0.70 & & \\
\hline $\begin{array}{l}\text { Tour guide, interpreters and the staff at visitor } \\
\text { center are properly dressed }\end{array}$ & 0.75 & 0.71 & & \\
\hline $\begin{array}{l}\text { The design, color and character size of the } \\
\text { signage are in harmony with the environment }\end{array}$ & 0.75 & 0.71 & & \\
\hline Empathy & 0.87 & & 0.87 & 0.57 \\
\hline The interpretive services meet visitors' needs & 0.85 & 0.71 & & \\
\hline $\begin{array}{l}\text { The staff at visitor center serve visitors with } \\
\text { patience }\end{array}$ & 0.84 & 0.73 & & \\
\hline $\begin{array}{l}\text { Interpreters provide appropriate interpretation for } \\
\text { visitors }\end{array}$ & 0.84 & 0.74 & & \\
\hline Personal interpretation satisfies visitors & 0.85 & 0.78 & & \\
\hline $\begin{array}{l}\text { The interpretive programs are rich in variety and } \\
\text { sufficient in quantity }\end{array}$ & 0.84 & 0.82 & & \\
\hline Assurance & 0.83 & & 0.83 & 0.55 \\
\hline The interpreter's expertise is trustworthy & 0.80 & 0.72 & & \\
\hline $\begin{array}{l}\text { The information on signage and printed materials } \\
\text { is completely correct }\end{array}$ & 0.80 & 0.69 & & \\
\hline $\begin{array}{l}\text { Interpreters and the staff at visitor center serve } \\
\text { visitors with courtesy }\end{array}$ & 0.78 & 0.77 & & \\
\hline Interpreters are competent for their job & 0.77 & 0.79 & & \\
\hline Responsiveness & 0.86 & & 0.86 & 0.61 \\
\hline $\begin{array}{l}\text { Visitors can get information about interpretive } \\
\text { services at visitor center }\end{array}$ & 0.85 & 0.71 & & \\
\hline $\begin{array}{l}\text { The heritage site provides visitors with the } \\
\text { interpretive services that satisfy them }\end{array}$ & 0.82 & 0.78 & & \\
\hline $\begin{array}{l}\text { The staff at visitor center are ready to serve } \\
\text { visitors }\end{array}$ & 0.81 & 0.83 & & \\
\hline $\begin{array}{lllll}\begin{array}{l}\text { Interpreters } \\
\text { precisely }\end{array} & \text { can } & \text { answer } & \text { visitors' questions } \\
\end{array}$ & 0.82 & 0.81 & & \\
\hline Reliability & 0.90 & & 0.90 & 0.65 \\
\hline $\begin{array}{l}\text { The visitor center can provide timely consultative } \\
\text { service for visitors }\end{array}$ & 0.89 & 0.79 & & \\
\hline $\begin{array}{l}\text { The staff at visitor center value the need of } \\
\text { visitors }\end{array}$ & 0.88 & 0.80 & & \\
\hline The interpretive services are reliable & 0.88 & 0.81 & & \\
\hline
\end{tabular}




\begin{tabular}{|c|c|c|c|c|}
\hline $\begin{array}{l}\text { The interpretive programs are used to the best } \\
\text { advantage }\end{array}$ & 0.99 & 0.82 & & \\
\hline $\begin{array}{l}\text { The heritage site provides quality interpretation } \\
\text { services for visitors }\end{array}$ & 0.88 & 0.82 & & \\
\hline Satisfaction & 0.88 & & 0.88 & 0.65 \\
\hline $\begin{array}{l}\text { I think my decision to use the interpretive services } \\
\text { when visiting the heritage site is correct }\end{array}$ & 0.86 & 0.78 & & \\
\hline $\begin{array}{l}\text { I'm pleased to use the interpretive services when } \\
\text { visiting the heritage site }\end{array}$ & 0.83 & 0.85 & & \\
\hline $\begin{array}{l}\text { Using interpretive services makes my visit here } \\
\text { very pleasant }\end{array}$ & 0.84 & 0.82 & & \\
\hline I'm satisfied with the interpretive services here & 0.86 & 0.77 & & \\
\hline \multicolumn{5}{|l|}{ Place attachment } \\
\hline Place dependence & 0.89 & & 0.89 & 0.63 \\
\hline $\begin{array}{l}\text { This is the best choice for historic heritage } \\
\text { tourism }\end{array}$ & 0.88 & 0.62 & & \\
\hline $\begin{array}{l}\text { Visiting this place satisfies me more than other } \\
\text { places }\end{array}$ & 0.86 & 0.79 & & \\
\hline Other heritage sites cannot replace my visit here & 0.85 & 0.83 & & \\
\hline No other heritage site is comparative to this place & 0.85 & 0.86 & & \\
\hline $\begin{array}{l}\text { My visit here is more important than visit to other } \\
\text { places }\end{array}$ & 0.86 & 0.83 & & \\
\hline Place identity & 0.91 & & 0.91 & 0.57 \\
\hline I always want to come here & 0.90 & 0.79 & & \\
\hline I like the heritage site very much & 0.90 & 0.82 & & \\
\hline I think this heritage site fits me well & 0.89 & 0.83 & & \\
\hline This heritage site is very special to me & 0.90 & 0.75 & & \\
\hline $\begin{array}{l}\text { I'm willing to spend more time visiting the } \\
\text { heritage site }\end{array}$ & 0.89 & 0.80 & & \\
\hline $\begin{array}{l}\text { Visiting this heritage site is of great significance } \\
\text { to me }\end{array}$ & 0.90 & 0.74 & & \\
\hline I think visiting this place is part of my life & 0.90 & 0.69 & & \\
\hline I'm proud of the heritage resources at the site & 0.90 & 0.58 & & \\
\hline \multicolumn{5}{|l|}{ Environmentally responsible behavior } \\
\hline On-site behavior & 0.88 & & 0.89 & 0.68 \\
\hline $\begin{array}{l}\text { Seeing others damage heritage items and the } \\
\text { environment, I'll stop them or report their } \\
\text { behaviors to the staff }\end{array}$ & 0.87 & 0.67 & & \\
\hline I don't litter at the heritage site & 0.82 & 0.87 & & \\
\hline $\begin{array}{l}\text { I'll protect the heritage resources and the } \\
\text { environment here }\end{array}$ & 0.83 & 0.86 & & \\
\hline $\begin{array}{l}\text { I'll obey the rules of heritage and environment } \\
\text { protection }\end{array}$ & 0.84 & 0.87 & & \\
\hline Off-site behavior & 0.81 & & 0.83 & 0.56 \\
\hline $\begin{array}{l}\text { I'm willing to learn how to protect the heritage } \\
\text { and environment here }\end{array}$ & 0.79 & 0.77 & & \\
\hline $\begin{array}{l}\text { I'm willing to talk about heritage and } \\
\text { environmental protection here with others }\end{array}$ & 0.73 & 0.83 & & \\
\hline $\begin{array}{l}\text { I'm willing to learn about the heritage and } \\
\text { environment protection via Internet, news etc. }\end{array}$ & 0.72 & 0.79 & & \\
\hline $\begin{array}{l}\text { I'm willing to donate money to protect the } \\
\text { historic heritage and the environment }\end{array}$ & 0.80 & 0.57 & & \\
\hline
\end{tabular}


Average variance extracted (AVE) was used to assess the validity of the scale. AVE exceeding 0.5 indicates good convergent validity. If the square root of the AVE is greater than the correlation coefficient of other variables, the discriminant validity is good. The result of the data analysis showed that the AVEs of all the dimensions were above 0.5 . The square root of the AVE was between 0.73 and 0.82 , which was greater than the corresponding correlation coefficient, indicating better convergent validity and discriminant validity (Table 3).

Table 3. Correlation matrix of the latent variables

\begin{tabular}{c|c|c|c|c|c|c|c|c|c|c|c|c}
\hline $\begin{array}{c}\text { Dimensions of } \\
\text { variables }\end{array}$ & Means & SD & $\mathbf{1}$ & $\mathbf{2}$ & $\mathbf{3}$ & $\mathbf{4}$ & $\mathbf{5}$ & $\mathbf{6}$ & $\mathbf{7}$ & $\mathbf{8}$ & $\mathbf{9}$ & $\mathbf{1 0}$ \\
\hline Tangibles & 4.40 & 0.94 & 0.73 & & & & & & & & & \\
\hline Empathy & 4.17 & 1.04 & 0.62 & 0.75 & & & & & & & & \\
\hline Assurance & 4.29 & 0.97 & 0.65 & 0.61 & 0.74 & & & & & & & \\
\hline Responsiveness & 4.26 & 1.03 & 0.54 & 0.65 & 0.62 & 0.78 & & & & & & \\
\hline Reliability & 3.23 & 1.08 & 0.51 & 0.53 & 0.59 & 0.63 & 0.81 & & & & & \\
\hline $\begin{array}{c}\text { Global } \\
\text { satisfaction }\end{array}$ & 3.35 & 1.05 & 0.67 & 0.53 & 0.52 & 0.54 & 0.60 & 0.81 & & & & \\
\hline Place dependence & 4.97 & 1.24 & 0.42 & 0.52 & 0.53 & 0.53 & 0.53 & 0.56 & 0.79 & & & \\
\hline Place identity & 4.00 & 1.14 & 0.39 & 0.42 & 0.47 & 0.46 & 0.50 & 0.56 & 0.54 & 0.75 & & \\
\hline On-site behavior & 5.89 & 0.91 & 0.29 & 0.22 & 0.32 & 0.23 & 0.18 & 0.34 & 0.23 & 0.26 & 0.82 & \\
\hline Off-site behavior & 5.64 & 0.99 & 0.33 & 0.36 & 0.45 & 0.39 & 0.34 & 0.45 & 0.40 & 0.44 & 0.69 & 0.75 \\
\hline
\end{tabular}

Using AMOS 24, the proposed model was tested by utilizing the Structural Equation Modeling (SEM) to measure the causal relationships within the model and the overall fitness of the model. The maximum likelihood estimation was applied to estimate all the parameters. Since a large size of samples may affect Chi-square $\left(\mathrm{x}^{2}\right)$ value, several other measurement model fit indices were used to determine whether the model fit was good. Model fit indicators include absolute fit indices and relative indices. Absolute fit indices include $x^{2} / \mathrm{df}(1-3)$, GFI $(\geq 0.9)$, AGFI $(\geq 0.9)$, RMR $(<0.05)$, RMSEA $(<0.08)$. The relative fit indices include NFI $(\geq 0.9)$, RFI $(\geq 0.9)$, CFI $(\geq 0.9)$ and IFI $(\geq 0.9)$.

\section{The testing results of hypothesis 1 and hypothesis 2}

The proposed model (Model l) (Fig. 4) was created to test whether interpretive service quality positively and significantly impacted on place attachment and ERB respectively. The test on goodness of fit indicated that all the indices were satisfying $(\mathrm{RMR}=0.06, \mathrm{RMSEA}=0.08 ; \mathrm{GFI}=0.94 ; \quad$ AGFI $=0.90 ; \quad \mathrm{NFI}=0.95 ; \quad \mathrm{RFI}=0.93$; CFI = 0.96; IFI =0.96). GFI, AGFI, NFI, RFI, CFI and IFI were within 0.90 and 1.00 . RMSEA was 0.08 and RMA was greater than 0.05 , a little bit higher than the threshold value of 0.05 , but it still indicated a good model fitness. In short, the above analysis result demonstrated a good model fitness (Table 4). According to the calculated path coefficient, interpretive service quality had direct and significant effect on place 
attachment $(\alpha 1=0.58)(\mathrm{p}<0.001)$. It proves that the higher interpretive service quality is, the stronger place attachment will be. Meanwhile, interpretive service affected ERB directly and significantly $(\alpha 2=0.45)(\mathrm{p}<0.001)$, which means that higher quality of interpretation elicits stronger intention of exhibiting ERB (Fig. 4).

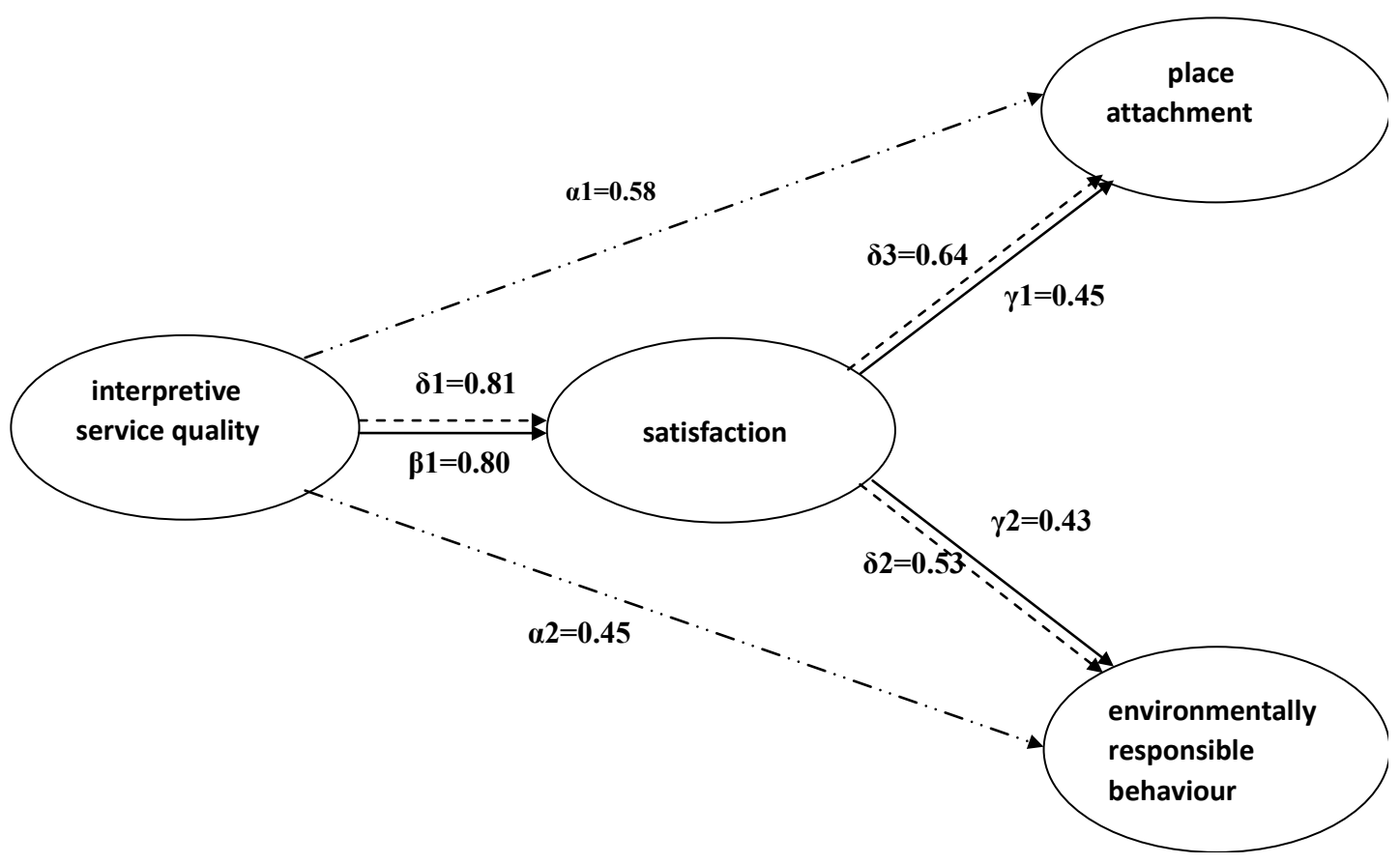

Figure 4. The model of satisfaction mediating effect

\section{The testing results of hypothesis $\mathrm{H}_{3}$, hypothesis $\mathrm{H}_{4}$ and hypothesis $\mathrm{H}_{5}$}

After confirming the positive direct effect of interpretive service quality on place attachment and ERB, the study further explored whether interpretive service quality impacted on satisfaction and whether satisfaction influenced place attachment and ERB respectively. The authors therefore established a model (Model 2) to test the abovementioned relationships. The goodness-of-fit indicators were as follows: $\mathrm{RMR}=0.04$; RMSEA $=0.07 ; \quad$ GFI $=0.94 ; \quad$ AGFI $=0.90 ; \quad$ NFI $=0.95 ; \quad$ RFI $=0.93 ; \quad$ CFI $=0.96 ;$ $\mathrm{IFI}=0.96$. GFI, AGFI, NFI, RFI, CFI and IFI were between 0.90 and 1.00 , while RMSEA (0.07) was a little bit lower than the cut-off point of 0.08 and RMR (0.04) was lower than 0.05. Therefore, the proposed model (Model 2) had a good fitness (Table 4). The path analysis results demonstrated that the direct effect of interpretive service quality on satisfaction was significant $(\beta 1=0.80)(\mathrm{p}<0.001)$, indicating that higher quality of interpretation makes tourists feel satisfied with the visited place. Furthermore, satisfaction affected place attachment $(\gamma 1=0.45)(\mathrm{p}<0.001)$ and ERB $(\gamma 2=0.43)$ $(\mathrm{p}<0.001)$ directly and significantly, showing that the more satisfied the tourists are with the destination, the stronger their emotional attachment to it and they are more willing to exhibit pro-environmental behavior. Thus, hypothesis3, hypothesis 4 and hypothesis5 are supported (Fig. 4). However, after entering satisfaction into the proposed model, the direct effect of interpretive service quality on place attachment and ERB were $0.22(\mathrm{p}<0.05)$ and $0.12(\mathrm{p}<0.05)$ respectively. It demonstrated that the direct effect of interpretive service quality on place attachment and ERB were much 
lower after entering the variable of satisfaction, indicating that the effect of interpretive service quality on place attachment and ERB were indirect, with the path coefficients being $0.36(0.80 \times 0.45)(\mathrm{p}<0.01)$ and $0.34(0.80 \times 0.43)(\mathrm{p}<0.01)$ respectively.

Based on the above analysis, satisfaction might mediate the relationship between interpretive service quality and place attachment as well as the relationship between interpretive service quality and ERB. Interpretation quality may not have direct causal relationship with place attachment and ERB. In other words, the original causal relationship might be influenced by a mediating variable. Therefore, the real causal relationship between interpretive service quality and place attachment as well as the causal relationship between interpretive service quality and ERB should be further explored.

To further explore the function of satisfaction in depth, the proposed model (Model 3) was created for path analysis. The results of the path analysis demonstrated that the proposed model had good fit indicators: $\mathrm{RMR}=0.04 ; \mathrm{RMSEA}=0.07$; $\mathrm{GFI}=0.94 ; \mathrm{AGFI}=0.91 ; \mathrm{NFI}=0.95 ; \mathrm{RFI}=0.94 ; \mathrm{CFI}=0.97 ; \mathrm{IFI}=0.97$. GFI, AGFI, NFI, RFI, CFI and IFI fell within 0.90 and 1.0. RMR was lower than the cut-off point of 0.05 and RMSEA was below the threshold value of 0.08 . Such analysis results indicated that the mediating model had good model fitness (Table 4). Further path analysis demonstrated that interpretive service influenced satisfaction positively $(\delta 1=0.81)(\mathrm{p}<0.001)$, establishing the causal relationship between the two. What is more, satisfaction exerted positive and significant influence on place attachment $(\delta 3=0.64)(\mathrm{p}<0.001)$ and ERB $(\delta 2=0.53)(\mathrm{p}<0.001)$ respectively. It indicates that the more satisfied the tourists are, the stronger their place attachment will be and they are more willing to show ERB. Path analysis also showed that interpretive service quality impacted place attachment $0.52 \quad(0.81 \times 0.64) \quad(\mathrm{p}<0.01)$ and ERB0.43 $(0.81 \times 0.53)(\mathrm{p}<0.01)$ indirectly through the mediating role of satisfaction. The results demonstrated that satisfaction had a full mediating effect on the relationship between interpretive service quality and place attachment and the relationship between interpretive service quality and ERB (Fig. 4). Such a finding is consistent with the study result about the mediating function of satisfaction between the relationship of service quality and behavioral outcomes by Fullerton and Taylor (2002).

Table 4. Fit indices for measurement model

\begin{tabular}{c|c|c|c|c|c}
\hline Fit indices & Criteria & Model 1 & Model2 & Model 3 & Model4 \\
\hline Absolute fit indices & & & & & \\
\hline GFI & $\geq 0.9$ & 0.94 & 0.94 & 0.94 & 0.94 \\
AGFI & $\geq 0.9$ & 0.90 & 0.90 & 0.91 & 0.91 \\
RMR & $<0.05$ & 0.06 & 0.04 & 0.04 & 0.04 \\
RMSEA & $<0.08$ & 0.08 & 0.07 & 0.07 & 0.07 \\
\hline Comparative fit indices & & & & & \\
\hline NFI & $\geq 0.9$ & 0.95 & 0.95 & 0.95 & 0.95 \\
RFI & $\geq 0.9$ & 0.93 & 0.93 & 0.94 & 0.94 \\
CFI & $\geq 0.9$ & 0.96 & 0.96 & 0.97 & 0.97 \\
IFI & $\geq 0.9$ & 0.96 & 0.96 & 0.97 & 0.97 \\
\hline
\end{tabular}




\section{The analysis results of hypothesis $\mathrm{H}_{6}$}

To examine the direct effect of place attachment on ERB, the path analysis of place attachment to ERB was added to establish the final structural model (Model 4) for this empirical study. The results showed a good model fitness: RMR $=0.04$; RMSEA $=0.07 ; \quad$ GFI $=0.94 ; \quad$ AGFI $=0.91 ; \quad$ NFI $=0.95 ; \quad$ RFI $=0.94 ; \quad$ CFI $=0.97$; IFI $=0.97$. GFI, AGFI, NFI, RFI, CFI and IFI ranged from0.90 to1.00. RMR was lower than the benchmark value of 0.05 and RMSEA was below the cut-off point of 0.08. All the figures demonstrated a good model fitness (Table 4). The path analysis indicated that place attachment influenced ERB positively and significantly 0.34 ( $\mathrm{p}<0.001)$. Therefore, stronger place attachment can facilitate stronger ERB. The effect of interpretive service on satisfaction was direct and positive $0.81(\mathrm{p}<0.001)$, showing that quality interpretation will satisfy the tourists. Path analysis also indicated that satisfaction affected place attachment 0.63 ( $p<0.001)$ and ERB $0.29(\mathrm{p}<0.001)$ directly and significantly. Namely, the more satisfied the tourists with the visited site, the stronger their emotional attachment and ERB will be.

Thus hypothesis 6 is supported. Meanwhile, satisfaction played a role of complete mediation in the relationship between interpretive service quality and place attachment and in the relationship between interpretive quality and ERB. As a result, interpretive service quality had indirect effect on place attachment through satisfaction, with a path coefficient of $0.51 \quad(p<0.01)$ and interpretive service quality impacted on ERB indirectly and significantly through satisfaction, with a path coefficient of 0.23 $(\mathrm{p}<0.01)$ (Fig. 5).

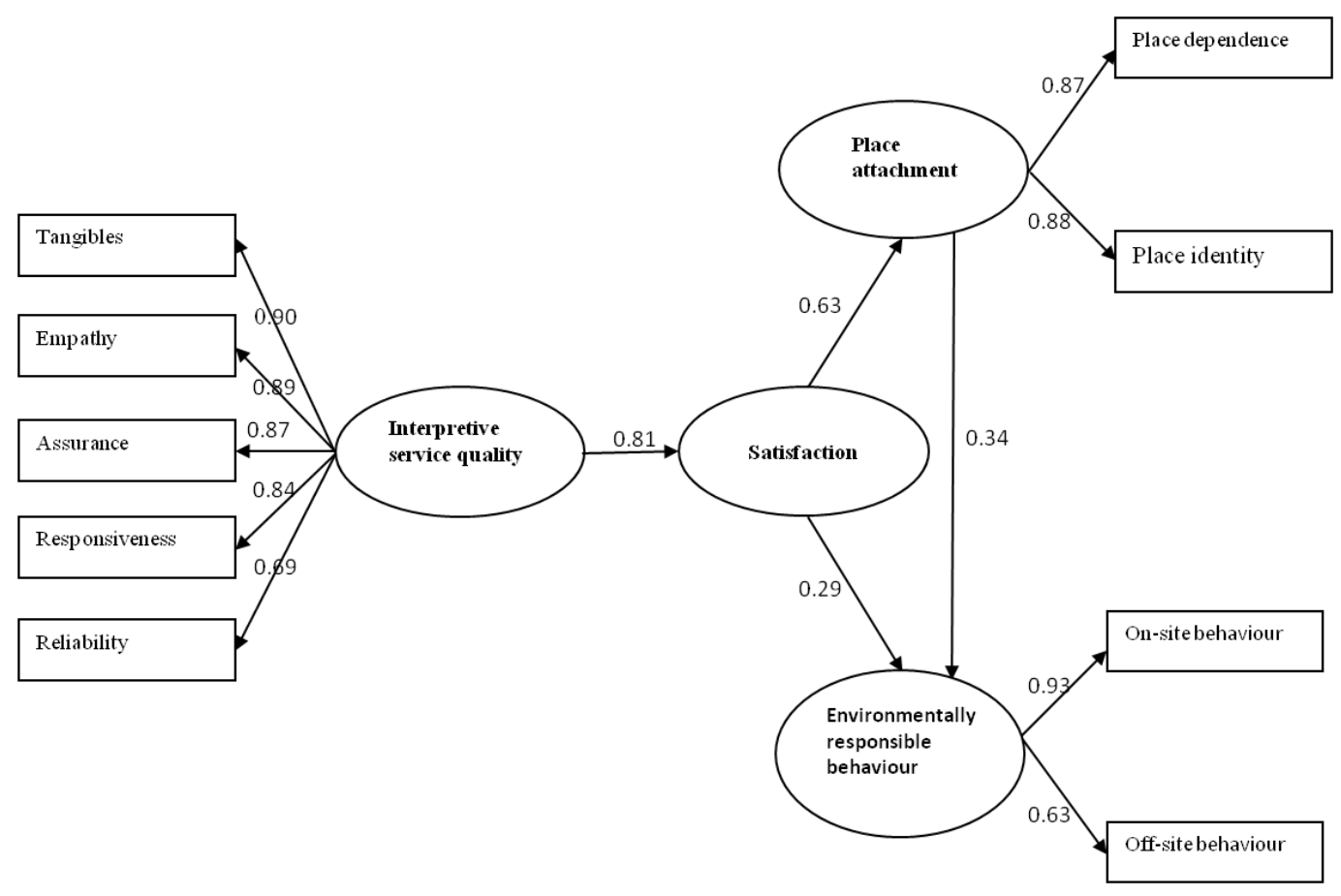

Figure 5. The structural model

\section{Discussion}

This study investigated the causal relationships among interpretive service quality, satisfaction, place attachment and ERB at five cultural heritage sites in $\mathrm{Xi}$ 'an. It is the 
first time in literature to simultaneously examine the structural relationships among these four variables in the same model. The findings showed that the causal relationship does exist between interpretive service quality and place attachment. Meanwhile, it is found that satisfaction plays a mediating role in the relationship between interpretive service quality and place attachment, which indicates that satisfaction with high quality of interpretive services will help tourists foster place attachment. The more satisfied tourists are with interpretive services, the stronger their place attachment to the visited sites will be. Second, the results also show that satisfaction mediates the relationship between interpretive service quality and ERB. Previous research showed that knowledge gain as a result of experiencing interpretation would elicit ERB among visitors, while this research demonstrates that satisfaction with interpretive service also helps visitors exhibit ERB. Third, the present study indicates that interpretive service affects satisfaction directly and significantly.

The results also demonstrate that tourists' satisfaction positively and significantly influences place attachment. Moreover, the present study shows that satisfaction with interpretive service helps facilitate visitors to demonstrate ERB at heritage sites, which supports the study results found by Moscardo (1996) and Powell and Ham (2008), indicating the importance of high quality of interpretive service at heritage sites. In addition, the young age of the respondents indicates that tourism management departments should strive to provide more vitalized interpretive programs such as well designed signage, movies using modern technology like $5 \mathrm{D}$ or $6 \mathrm{D}$, the live programs that young visitors may get involved in to satisfy them. In addition, very few visitors using web sites of the destination to obtain information about the visited sites indicates that tourism management agency should design fantastic web sites with amazing pictures as well as convincing descriptions, which is very informative, attractive and at the same time easy to access, to attract more visitors from outside of Shaanxi province. What is more, larger number of respondents relying on personal interpretation to help them understand the visited heritage sites implies that tour guides should be trained to do their work more efficiently in order to meet the needs of the visitors. Since nearly half of the respondents turn to various signs for getting the information about the destination, well designed and properly located signage are very important to serve the visitors.

\section{Conclusions}

Based on the results of this study, the following conclusions can be reached: (1) relationship between interpretive service and place attachment does exist and the former affects the latter indirectly and significantly, with satisfaction playing a mediating role between them. (2) interpretive service influences ERB indirectly and satisfaction plays a mediating role in the relationship between the two. (3) The direct effect of interpretive service on satisfaction is positive. Meanwhile, satisfaction exerts direct influence on place attachment and ERB respectively; (4) place attachment impacts ERB directly.

The findings of this study demonstrate the importance of interpretive service quality in facilitating place attachment and ERB among tourists. High quality of interpretive services is beneficial to satisfying tourists and enriching their travel experience, which leads to their place attachment to the destination. In addition, satisfaction with high quality of interpretive services and place attachment will elicit ERB among tourists and such pro-environmental behavior will contribute to the tourist management as well as 


$$
-6333 \text { - }
$$

heritage resource management. Ultimately, sustainable use of heritage resources and sustainable development of heritage tourism will be achieved. Therefore, it is very necessary for tourism management agency to improve interpretive service quality.

\section{Limitations}

The research limitations are as follows: First, the authors of this study did not analyze how each dimension of interpretive service affected satisfaction respectively. Second, the study did not examine the mediating role of place attachment in the relationship between satisfaction and ERB. Third, the historic sites selected for the study were of higher ranking sites and those of lower ranking were not included. To test the universality of the proposed model, historic sites of different ranking should be investigated. Future research may avoid the above limitations and further explore the outcomes of interpretation in depth.

Acknowledgements. 1. A Study of Optimization of Interpretive System in Tourist Destinations in Shaanxi (2013JK0301), funded by Shaanxi Education Department. 2. A Study of Affective and Behavioral Outcomes of Interpretive Services in Cultural Heritage Sites in Shaanxi (2017S006), funded by Shaanxi Social Science Academy.

\section{REFERENCES}

[1] Alexandris, K., Kouthouris, C., Melogdis, A. (2006): Increasing customers' loyalty in a skiing resort: The contribution of place attachment and service quality. - International Journal of Contemporary Hospitality Management 18: 414-425.

[2] Ajzen, I. (1991): The theory of planned behavior. - Organizational Behavior and Human Decision Processes 50: 179-211.

[3] Baker, D. A., Crompton, J. L. (2000): Quality, satisfaction and behavioral intentions. Annals of Tourism Research 27(3): 785-804.

[4] Ballantyne, R., Packer, J. (2011): Using tourism free-choice learning experiences to promote environmentally sustainable behavior: The role of post-visit "action resources". - Environmental Education Research 17(2): 201-215.

[5] Ballantyne, R., Packer, J., Hughes, K. (2009): Tourists' support for conservation messages, and sustainable management practices in wildlife experiences. - Tourism Management 30(5): 658-664.

[6] Ballantyne, R., Packer, J., Falk, J. (2011): Visitors' learning for environmental sustainability: testing short-and long-term impacts of wildlife tourism experiences using structural equation modelling. - Tourism Management 32(6): 1243-1252.

[7] Battour, M., Battor, M., Bhatti, M. A. (2014): Islamic attributes of destination: construct development and measurement validation, and their impact on tourist satisfaction. International Journal of Tourism Research 16(6): 556-564.

[8] Bernini, C., Cagnone, S. (2014): Analysing tourist satisfaction at a mature and multiproduct destination. - Current Issues in Tourism 17(1): 1-20.

[9] Carr, A. (2004): Mountain places, cultural spaces: The interpretation of culturally significant landscapes. - International Journal of Heritage Studies 12(5): 432-459.

[10] Chen, C. F., Chen, F. S. (2010): Experience quality, perceived value, satisfaction and behavioral intentions for heritage tourists. - Tourism Management, (31): 29-35.

[11] Cheng, T. M., Wu, H. C., Huang, L. M. (2013): The influence of place attachment on the relationship between destination attractiveness and environmentally responsible behavior 
for island tourism in Penghu, Taiwan. - Journal of Sustainable Tourism 21(8): 11661187.

[12] Cronin Jr, J. J., Taylor, S. A. (1994): SERVPERF versus SERVQUAL: Reconciling performance-based and perceptions-minus-expectations measurement of service quality. - Journal of Marketing 58(1): 125-131.

[13] Davis, J. L., Le, B., Coy, A. E. (2011): Building a model of commitment to the environment to predict ecological behavior and willingness to sacrifice. - Journal of Environmental Psychology 31: 257-265.

[14] Fishbein, M. A., Ajzen, I. (1975): Belief, attitude, intention, and behavior: An introduction to theory and research. - Addison-Wesley, Reading, MA.

[15] George, B. P., George, B. P. (2004): Past visit and the intention to revisit a destination: Place attachment as a mediator and novelty seeking as the moderator. - The Journal of Tourism Studies 15(2): 51-66.

[16] Goldman, T., Chen, J., Larsen, D. (2001): Clicking the icon: Exploring the meanings visitors attach to three national capital memorials. - Journal of Interpretation Research 6(1): 3-30.

[17] Graham, B. (2007) Heritage as Knowledge: Capital or Culture? - In: Smith, L. (ed.) Cultural Heritage: Critical Concepts in Media and Cultural Studies. Routledge, London pp. 249-268.

[18] Hall, C. M., Mcarthur, S. (1998): Integrated Heritage Management: Principles and Practice. - The Stationary Office, London.

[19] Halpenny, E. A. (2005): Pro-environment intentions: Examining the affect of place attachment, environmental attitudes toward pro-environmental behavior. - Paper presented at the Eleventh Canadian Congress on Leisure Research, May 17-25, 2005, Department of Recreation and Tourism Management, Malaspina University-College, Nanaimo, B.C.

[20] Halpenny, E. A. (2010): Pro-environmental behaviors and park visitors: The effect of place attachment. - Journal of Environmental Psychology 30: 409-421.

[21] Ham, S., Weiler, B. (2006): Development of a Research-based Tool for Evaluating Interpretation. - CRC for Sustainable Tourism, Gold Coast, Qld.

[22] Ham, S., Weiler, B. (2007): Isolating the role of on-site interpretation in a satisfying experience. - Journal of Interpretation Research 12(2): 5-24.

[23] Hinds, J., Sparks, P. (2008): Engaging with the natural environment: The role of affective connection and identity. - Journal of Environmental Psychology 28(2): 109-120.

[24] Hou, J. S., Lin, C. H., Morais, D. B. (2005): Antecedents of attachment to a cultural tourism destination: The case of Hakka and non-Hakka Taiwanese visitors to Pei-Pu, Taiwan. - Journal of Travel Research 44: 221-223.

[25] Huang, S., Weiler, B., Assaker, G. (2015): Effects of interpretive guiding outcomes on tourist satisfaction and behavioral intention. - Journal of Travel Research 54(3): 344-358.

[26] Hughes, M. (2004): Influence of varying intensities of natural area on-site interpretation on attitudes and knowledge. $-\mathrm{PhD}$ Thesis, Murdoch University, Australia.

[27] Kim, A., Airey, D., Szivas, E. (2011): The multiple assessment of interpretation effectiveness: promoting visitors' environmental attitudes and behavior. - Journal of Travel Research 50(3): 321-334.

[28] Knudson, D., Cable, T., Beck, L. (2003): Interpretation of Cultural and Natural Resources. - Venture Publishing, State College, PA.

[29] Larsen, D. L. (ed.) (2003): Meaningful Interpretation: How to Connect Hearts and Minds to Places, Objects, and Other Resources. - Eastern National, Fort washing, PA.

[30] Lee, C., Backman, K., Backman, S. (1997): Understanding Antecedents of Repeat Visitation and Tourists' Loyalty to a Resort Destination. - In: Proceedings of the 1997 Travel and Tourism Research Association Annual Conference. TTRA, Boulder, CO. 
[31] Lee, T. H. (2009): A structural model for examining how destination image and interpretation services affect future visitation behavior: a case study of Taiwan's Taomi eco-village. - Journal of Sustainable Tourism 17(6): 727-745.

[32] Lee, T. H. (2011): How recreation involvement, place attachment and conservation commitment affect environmentally responsible behavior. - Journal of Sustainable Tourism 19(7): 895-915.

[33] Lee, T. H., Jan, F. H., Yang, C. C. (2013a): Environmentally responsible behavior of nature-based tourists: A review. - International Journal of Development and Sustainability 2(1):100-115.

[34] Lee, T. H., Jan, F. H., Yang, C. C. (2013b): Conceptualizing and measuring environmentally responsible behaviors from the perspective of community-based tourists. - Tourism Management 36: 454-468.

[35] Lee, W. H., Moscardo, G. (2005): Understanding the impact of ecotourism resort experiencing on tourists' environmental attitudes and behavioral intentions. - Journal of Sustainable Tourism 13(6): 546-565.

[36] Lopez-Mosquera, N., Sanchez, M. (2011): Emotional and satisfaction benefits to visitors as explanatory factors in the monetary evaluation of environmental goods. An application to periurban green spaces. - Land Use Policy 28(1): 151-166.

[37] Low, S., Altman, I. (1992): Place Attachment: A conceptual Inquiry. - In: Althman, I., Low, S. (eds.) Place Attachment. Plenum, New York.

[38] Ma, Y. F., Song, B. P., Zhao, Z. B. (2007): Research and Evaluation of Tourism Resources in Shaanxi Province. - Science Publishing House, Beijing.

[39] Mace, B. L., McDaniel, J. (2013): Visitor evaluation of night sky interpretation in Bryce Canyon National Park and Cedar Breaks National Monument. - Journal of Interpretation Research 18(1): 39-57.

[40] Marion, J., Reid, S. (2007): Minimizing visitor impacts to protected areas: the efficacy of low impact education programs. - Journal of Sustainable Tourism 15(1): 5-27.

[41] Morgan, M. (2009): Interpretation and place attachment: implications for cognitive map theory. - Journal of Interpretation Research 14(1):47-59.

[42] Morgan, M., Hwang, G. (2014): Perception of thematic-based interpretation at the Jefferson National Expansion Memorial - A study of Korean visitors. - Journal of Interpretation Research 19(2): 25-37.

[43] Moscardo, G. (1996): Mindful visitors: heritage and tourism. - Annals of Tourism Research 23(2):376-397.

[44] Moscardo, G. (2014): Interpretation and tourism: holy grail or emperor's robes? International Journal of Culture. - Tourism and Hospitality Research 8(4): 462 - 476.

[45] Munro, J. K., Morrison-Saunders, A., Hughes, M. (2008): Environmental interpretation evaluation in natural areas. - Journal of Ecotourism 7(1): 1-15.

[46] Oliver, R. L. (1980): A cognitive model of the antecedents and consequences of satisfaction decisions. - Journal of Marketing Research 17: 460-469.

[47] Petrick, J. F., Backman, S. J., Bixler, R. (1999): An investigation of selected factors' impact on golfer satisfaction and perceived value. - Journal of Park and Recreation Administration 17(1): 40-59.

[48] Poria, Y., Reichel, A., Biran, A. (2006): Heritage site management: motivations and expectations. - Annals of Tourism Research 33(1): 162-178.

[49] Poria, Y., Biran, A., Reichel, A. (2009): Visitors' preferences for interpretation at heritage sites. - Journal of Travel Research 48(1): 92-105.

[50] Powell, R. B., Ham, S. H. (2008): Can ecotourism interpretation really lead to proconservation knowledge, attitudes and behavior? Evidence from the Galapagos Islands. Journal of Sustainable Tourism 16(4): 467-489.

[51] Prayag, G., Ryan, C. (2012): Antecedents of tourists' loyalty to Mauritius: the role and influence of destination image, place attachment, personal involvement, and satisfaction. - Journal of Travel Research 51(3): 342-356. 
[52] Ramkissoon, H., Mavondo, F. (2014): Pro-environmental behavior: The link between place attachment and place satisfaction. - Tourism Analysis 19: 673-688.

[53] Ramkissoon, H., Mavondo, F. (2015): The satisfaction-place attachment relationship: Potential mediators and moderators. - Journal of Business Research 68: 2593-2602.

[54] Ramkissoon, H., Weiler, B., Smith, LDG. (2013): Place attachment, place satisfaction and pro-environmental behavior: a comparative assessment of multiple regression and structural equation modelling, - Journal of Policy Research in Tourism, Leisure and Events 5(3): 215-232.

[55] Raymond, C., Brown, G., Weber, D. (2010): The measurement of place attachment: Personal, community, and environmental Connections. - Journal of Environmental Psychology 30: 422-434.

[56] Risk, P. (1982): The Interpretive Talk. - In: Sharpe, G. (ed.) Interpreting the Environment. John Wiley \& Sons, New York, NY (pp. 194-213).

[57] Schultz, P. W., Shriver, C., Tabanico, J. J., Khazian, A. M. (2004): Implicit connections with nature. - Journal of Environmental Psychology 24(1): 31-42.

[58] Sivek, D., Hungerford, H. R. (1990): Predictors of responsible environmental behavior in members of three Wisconsin conservation organizations. - Journal of Environmental Education 21: 35-40.

[59] Skibins, J. C., Powell, R. B., Stern, M. J. (2011) Exploring empirical support for interpretation's best practices. - Journal of Interpretation Research 17(1): 25-44.

[60] Smith-Sebasto, N. J., D’Costa, A. (1995): Designing a Likert-type scale to predict environmentally responsible behavior in undergraduate students: a multistep process. The Journal of Environmental Education 27(1):14-20.

[61] Song, H. Q., Cheung, C. (2010): Factors affecting tourist satisfaction with theatrical performances: a case study of the romance of the Song Dynasty in Hangzhou, China. Journal of Travel \& Tourism Marketing 27(7): 708-722.

[62] Stern, P. C. (2000): Toward a coherent theory of environmentally significant behavior. Journal of Social Issues 56(3): 407-424.

[63] Su, H. J., Cheng, K. F., Huang, H. H. (2011): Empirical study of destination loyalty and its antecedent: the perspective of place attachment. - The Service Industries Journal 31(16): 2721-2739.

[64] Tilden, F. (2007): Interpreting Our Heritage (Fourth Ed.) - The University of North Carolina Press, Chapel Hill, NC.

[65] Trentelman, C. K. (2009): Place attachment and community attachment: A primer grounded in the lived experience of a community sociologist. - Society and Natural Resources 22: 191-210.

[66] Tubb, K. N. (2003): An evaluation of the effectiveness of interpretation within Dartmoor National Park in reaching the goals of sustainable tourism development. - Journal of Sustainable Tourism 11(6): 476-498.

[67] Ward, C., Wilkinson, A. (2006): Personal Interpretation - a Field Guide for Success. Fulcrum Applied Communication Series, Fulcrum Books, Golden, Colorado.

[68] Williams, D. R., Roggenbuck, J. W. (1989): Measuring place attachment: Some preliminary results. - Paper presented at the Symposium on Outdoor Recreation Planning and Management, National Recreation and Park Association Research Symposium on Leisure Research, San Antonio, TX.

[69] Williams, D. R., Vaske, J. (2003): The measurement of place attachment: Validity and generalizability of a psychometric approach. - Forest Science 49: 830-840.

[70] Xu, Z. X., Zhang, J. (2016) Antecedents and consequences of place attachment: A comparison of Chinese and Western urban tourists in Hangzhou, China. - Journal of Destination Marketing \& Management 5(2):86-96.

[71] Yuksel, A., Yuksel, F., Bilim, Y. (2010): Destination attachment: Effects on customer satisfaction and cognitive, affective and connative loyalty. - Tourism Management 31(2): 274-284. 
[72] Zabkar, V., Brencic, M. M., Dmitrovic, T. (2010): Modeling perceived quality, visitor satisfaction and behavioral intentions at the destination level. - Tourism Management 31: 537-546.

\section{APPENDIX}

\section{VISITOR SURVEY}

In this survey we would like to ask you some questions about the place you visited today. Your cooperation will help us make some important management suggestions about the service quality of this place. Your honest, personal opinions are important. It will take you about 10 minutes to complete it. Thanks for your time!

\section{Northwest University}

\section{Your evaluations of the interpretive service quality}

How would you evaluate the service quality of this place? Please score each item. "1" represents" Strongly Disagree "(SD), "4 " for "Neutral"(N) and "7" for "Strongly Agree" (SA).

\begin{tabular}{|c|c|c|c|c|c|c|c|}
\hline Statements & SD & & & $\mathbf{N}$ & & & SA \\
\hline $\begin{array}{l}\text { 1. The digital interpretive programs at the heritage site } \\
\text { provide effective interpretation. }\end{array}$ & 1 & 2 & $\mathbf{3}$ & 4 & 5 & 6 & 7 \\
\hline 2. The signage and tour route signs are easily spotted. & 1 & 2 & $\mathbf{3}$ & 4 & 5 & 6 & 7 \\
\hline $\begin{array}{l}\text { 3. Tour guide, interpreters and the staff at visitor center } \\
\text { are properly dressed. }\end{array}$ & 1 & 2 & 3 & 4 & 5 & 6 & 7 \\
\hline $\begin{array}{l}\text { 4. The design, color and character size of the signage are } \\
\text { in harmony with the environment. }\end{array}$ & 1 & 2 & 3 & 4 & 5 & 6 & 7 \\
\hline 5. The interpretive services meet visitors' needs. & 1 & 2 & $\mathbf{3}$ & 4 & 5 & 6 & 7 \\
\hline 6. The staff at visitor center serve visitors with patience. & 1 & 2 & $\mathbf{3}$ & 4 & 5 & 6 & 7 \\
\hline $\begin{array}{l}\text { 7. Interpreters provide appropriate interpretation for } \\
\text { visitors. }\end{array}$ & 1 & 2 & 3 & 4 & 5 & 6 & 7 \\
\hline 8. Personal interpretation satisfies visitors. & 1 & 2 & 3 & 4 & 5 & 6 & 7 \\
\hline $\begin{array}{l}\text { 9. The interpretive programs are rich in variety and } \\
\text { sufficient in quantity. }\end{array}$ & 1 & 2 & 3 & 4 & 5 & 6 & 7 \\
\hline 10. The interpreter's expertise is trustworthy. & $\mathbf{1}$ & 2 & 3 & 4 & 5 & 6 & 7 \\
\hline $\begin{array}{l}\text { 11. The information on signage and printed materials is } \\
\text { completely correct. }\end{array}$ & 1 & 2 & 3 & 4 & 5 & 6 & 7 \\
\hline $\begin{array}{l}\text { 12. Interpreters and the staff at visitor center serve } \\
\text { visitors with courtesy. }\end{array}$ & 1 & 2 & 3 & 4 & 5 & 6 & 7 \\
\hline 13. Interpreters are competent for their job. & $\mathbf{1}$ & 2 & 3 & 4 & 5 & 6 & 7 \\
\hline $\begin{array}{l}\text { 14. Visitors can get information about interpretive } \\
\text { services at visitor center. }\end{array}$ & 1 & 2 & 3 & 4 & 5 & 6 & 7 \\
\hline $\begin{array}{l}\text { 15. The heritage site provides visitors with the } \\
\text { interpretive services that satisfy them. }\end{array}$ & 1 & 2 & 3 & 4 & 5 & 6 & 7 \\
\hline 16. The staff at visitor center are ready to serve visitors. & $\mathbf{1}$ & 2 & $\mathbf{3}$ & 4 & 5 & 6 & 7 \\
\hline 17. Interpreters can answer visitors' questions precisely. & 1 & 2 & 3 & 4 & 5 & 6 & 7 \\
\hline $\begin{array}{l}\text { 18. The visitor center can provide timely consultative } \\
\text { service for visitors. }\end{array}$ & 1 & 2 & 3 & 4 & 5 & 6 & 7 \\
\hline 19. The staff at visitor center value the need of visitors. & 1 & 2 & 3 & 4 & 5 & 6 & 7 \\
\hline 20. The interpretive services are reliable. & 1 & 2 & 3 & 4 & 5 & 6 & 7 \\
\hline $\begin{array}{l}\text { 21. The interpretive programs are used to the best } \\
\text { advantage. }\end{array}$ & 1 & 2 & 3 & 4 & 5 & 6 & 7 \\
\hline $\begin{array}{l}\text { 22. The heritage site provides quality interpretation } \\
\text { services for visitors. }\end{array}$ & 1 & 2 & 3 & 4 & 5 & 6 & 7 \\
\hline
\end{tabular}


Your satisfaction with the visited place

How much are you emotionally attached to this tourist attraction? Please score each item by circling the number. "1" represents "Strongly Disagree"(SD), "4 " for "Neutral"(N) and "7" for "Strongly Agree" (SA)

\begin{tabular}{|l|c|c|c|c|c|c|c|}
\hline \multicolumn{1}{|c|}{ Statements } & SD & & & N & & & SA \\
\hline $\begin{array}{l}\text { 23. I think my decision to use the interpretive services } \\
\text { when Visiting the heritage site is correct. }\end{array}$ & $\mathbf{1}$ & $\mathbf{2}$ & $\mathbf{3}$ & $\mathbf{4}$ & $\mathbf{5}$ & $\mathbf{6}$ & $\mathbf{7}$ \\
\hline $\begin{array}{l}\text { 24. I'm pleased to use the interpretive services when } \\
\text { visiting the heritage site. }\end{array}$ & $\mathbf{1}$ & $\mathbf{2}$ & $\mathbf{3}$ & $\mathbf{4}$ & $\mathbf{5}$ & $\mathbf{6}$ & $\mathbf{7}$ \\
\hline $\begin{array}{l}\text { 25. Using interpretive services makes my visit here very } \\
\text { pleasant. }\end{array}$ & $\mathbf{1}$ & $\mathbf{2}$ & $\mathbf{3}$ & $\mathbf{4}$ & $\mathbf{5}$ & $\mathbf{6}$ & $\mathbf{7}$ \\
\hline 26. I'm satisfied with the interpretive services here. & $\mathbf{1}$ & $\mathbf{2}$ & $\mathbf{3}$ & $\mathbf{4}$ & $\mathbf{5}$ & $\mathbf{6}$ & $\mathbf{7}$ \\
\hline
\end{tabular}

\section{Your emotional attachment to the visited site}

How much are you emotionally attached to this tourist attraction? Please score each item. "1" represents" Strongly Disagree"(SD), "4 " for "Neutral"(N) and "7" for "Strongly Agree" (SA)

\begin{tabular}{|l|c|c|c|c|c|c|c|}
\hline \multicolumn{1}{|c}{ Statements } & SD & & & $\mathbf{N}$ & & & SA \\
\hline 27. This is the best choice for historic heritage tourism. & $\mathbf{1}$ & $\mathbf{2}$ & $\mathbf{3}$ & $\mathbf{4}$ & $\mathbf{5}$ & $\mathbf{6}$ & $\mathbf{7}$ \\
\hline $\begin{array}{l}\text { 28. Visiting this place satisfies me more than other } \\
\text { places. }\end{array}$ & $\mathbf{1}$ & $\mathbf{2}$ & $\mathbf{3}$ & $\mathbf{4}$ & $\mathbf{5}$ & $\mathbf{6}$ & $\mathbf{7}$ \\
\hline 29. Other heritage sites cannot replace my visit here. & $\mathbf{1}$ & $\mathbf{2}$ & $\mathbf{3}$ & $\mathbf{4}$ & $\mathbf{5}$ & $\mathbf{6}$ & $\mathbf{7}$ \\
\hline 30. No other heritage site is comparative to this place. & $\mathbf{1}$ & $\mathbf{2}$ & $\mathbf{3}$ & $\mathbf{4}$ & $\mathbf{5}$ & $\mathbf{6}$ & $\mathbf{7}$ \\
\hline $\begin{array}{l}\text { 31. My visit here is more important than visit to other } \\
\text { places. }\end{array}$ & $\mathbf{1}$ & $\mathbf{2}$ & $\mathbf{3}$ & $\mathbf{4}$ & $\mathbf{5}$ & $\mathbf{6}$ & $\mathbf{7}$ \\
\hline 32. I always want to come here. & $\mathbf{1}$ & $\mathbf{2}$ & $\mathbf{3}$ & $\mathbf{4}$ & $\mathbf{5}$ & $\mathbf{6}$ & $\mathbf{7}$ \\
\hline 33. I like the heritage site very much. & $\mathbf{1}$ & $\mathbf{2}$ & $\mathbf{3}$ & $\mathbf{4}$ & $\mathbf{5}$ & $\mathbf{6}$ & $\mathbf{7}$ \\
\hline 34. I think this heritage site fits me well. & $\mathbf{1}$ & $\mathbf{2}$ & $\mathbf{3}$ & $\mathbf{4}$ & $\mathbf{5}$ & $\mathbf{6}$ & $\mathbf{7}$ \\
\hline 35. This heritage site is very special to me. & $\mathbf{1}$ & $\mathbf{2}$ & $\mathbf{3}$ & $\mathbf{4}$ & $\mathbf{5}$ & $\mathbf{6}$ & $\mathbf{7}$ \\
\hline $\begin{array}{l}\text { 36. I'm willing to spend more time visiting the } \\
\text { heritage site. }\end{array}$ & $\mathbf{1}$ & $\mathbf{2}$ & $\mathbf{3}$ & $\mathbf{4}$ & $\mathbf{5}$ & $\mathbf{6}$ & $\mathbf{7}$ \\
\hline $\begin{array}{l}\text { 37. Visiting this heritage site is of great significance to } \\
\text { me. }\end{array}$ & $\mathbf{1}$ & $\mathbf{2}$ & $\mathbf{3}$ & $\mathbf{4}$ & $\mathbf{5}$ & $\mathbf{6}$ & $\mathbf{7}$ \\
\hline 38. I think visiting this place is part of my life. & $\mathbf{1}$ & $\mathbf{2}$ & $\mathbf{3}$ & $\mathbf{4}$ & $\mathbf{5}$ & $\mathbf{6}$ & $\mathbf{7}$ \\
\hline 39. I'm proud of the heritage resources at the site. & & & $\mathbf{6}$ & $\mathbf{7}$ \\
\hline
\end{tabular}

\section{Your behaviors exhibited on and off the visited site}

What were or would be your behaviors exhibited on and off the visited site? Please score each item. "1" represents" Strongly Disagree "(SD), "4" for "Neutral"(N) and "7" for "Strongly Agree" (SA)

\begin{tabular}{|l|c|c|c|c|c|c|c|}
\hline \multicolumn{1}{|c|}{ Statements } & SD & & $\mathbf{N}$ & & $\mathbf{S A}$ \\
\hline $\begin{array}{l}\text { 40. Seeing others damage heritage items and the } \\
\text { environment, I'll stop them or report their behaviors to } \\
\text { the staff. }\end{array}$ & $\mathbf{1}$ & $\mathbf{2}$ & $\mathbf{3}$ & $\mathbf{4}$ & $\mathbf{5}$ & $\mathbf{6}$ & $\mathbf{7}$ \\
\hline 41. I don't litter at the heritage site. & $\mathbf{1}$ & $\mathbf{2}$ & $\mathbf{3}$ & $\mathbf{4}$ & $\mathbf{5}$ & $\mathbf{6}$ & $\mathbf{7}$ \\
\hline $\begin{array}{l}\text { 42. I'll protect the heritage resources and the } \\
\text { environment here. }\end{array}$ & $\mathbf{1}$ & $\mathbf{2}$ & $\mathbf{3}$ & $\mathbf{4}$ & $\mathbf{5}$ & $\mathbf{6}$ & $\mathbf{7}$ \\
\hline $\begin{array}{l}\text { 43. I'll obey the rules of heritage and environment } \\
\text { protection. }\end{array}$ & $\mathbf{1}$ & $\mathbf{2}$ & $\mathbf{3}$ & $\mathbf{4}$ & $\mathbf{5}$ & $\mathbf{6}$ & $\mathbf{7}$ \\
\hline $\begin{array}{l}\text { 44. I'm willing to learn how to protect the heritage and } \\
\text { environment here. }\end{array}$ & $\mathbf{1}$ & $\mathbf{2}$ & $\mathbf{3}$ & $\mathbf{4}$ & $\mathbf{5}$ & $\mathbf{6}$ & $\mathbf{7}$ \\
\hline $\begin{array}{l}\text { 45. I'm willing to talk about heritage and environmental } \\
\text { protection here with others. }\end{array}$ & $\mathbf{1}$ & $\mathbf{2}$ & $\mathbf{3}$ & $\mathbf{4}$ & $\mathbf{5}$ & $\mathbf{6}$ & $\mathbf{7}$ \\
\hline $\begin{array}{l}\text { 46. I'm willing to learn about the heritage and } \\
\text { environment protection via Internet, news etc. }\end{array}$ & $\mathbf{1}$ & $\mathbf{2}$ & $\mathbf{3}$ & $\mathbf{4}$ & $\mathbf{5}$ & $\mathbf{6}$ & $\mathbf{7}$ \\
\hline $\begin{array}{l}\text { 47. I'm willing to donate money to protect the historic } \\
\text { heritage and the environment. }\end{array}$ & $\mathbf{1}$ & $\mathbf{2}$ & $\mathbf{3}$ & $\mathbf{4}$ & $\mathbf{5}$ & $\mathbf{6}$ & $\mathbf{7}$ \\
\hline
\end{tabular}




$$
-6339-
$$

Your gender: $\square$ male $\square$ female

\section{$\underline{\text { Demographic traits }}$}

Age: $\square<18 \quad \square 18-28 \quad \square 29-39 \quad \square 40-50 \quad \square 51-60 \quad \square>60$

Marital status: $\square$ unmarried $\square$ married

Education: ajunior high school \& below $\square$ senior high school

$$
\square \text { college } \quad \square \text { graduate school }
$$

Companions: $\square$ package tour $\quad \square$ travel alone $\quad \square$ with friends

口with families $\quad$ awith friends and families

Residence: $\square$ Shaanxi province $\quad \square$ Mainland province outside Shaanxi

$$
\square \text { Hong Kong, Maocao and Taiwan } \quad \square \text { Overseas }
$$

Past experiences: $\square$ First time $\square$ Second time $\square$ Third time

Visiting time: $\square$ 1hour $\square 2$ hours $\square 3$ hours $\square$ 4hours

Visiting purpose (you may choose more than one answer):

口seeking nostalgia experience $\quad$ broaden horizons $\quad$ relax and relieve pressure $\square$ attracted by the reputation $\square$ To accompany others $\square$ other reasons

\section{Interpretive services used}

$\square$ personal interpretation $\square$ signage $\square$ digital interpretive programs $\square$ printed materials

口visitor center $\quad \square$ films $\square$ on-site activities $\quad \square$ websites

\section{THANKS FOR YOUR COOPERATION!}

